\title{
IT DIDN'T HAPPEN HERE: WHY SOCIALISM FAILED IN THE UNITED STATES
}

Seymour Martin Lipset and Gary Marks, New York: London: W.W. Norton \& Company, 2001. 379 pp. ISBN 0-393-32254-8.

Jorge Pereira*

jorge_pereira@portugalmail.pt

Although first published in 2000, the current economic crisis has lent new relevance to the subject of this work. Current events in America make it worthwhile to return to this book wherein Seymour Martin Lipset and Gary Marks analyse the failure of Socialism to get a firm hold in America. Despite the downturn in Capitalism's fortunes, rising unemployment and public dissatisfaction as manifested in the Occupy Wall Street protests, the fact is that, as far as anyone can tell, there is no prospect of it developing a Socialist mass-movement in America. Therefore, the question of "why there is no socialism in the United States' becomes, by way of present circumstances, as sharp as ever.

The authors begin by reminding us that the United States were expected to be the leading nation in ushering the global social revolution and overthrow of Capitalism worldwide. Indeed, Marxist theory prescribed the triumph of Socialism in the United States as "inevitable". As Karl Marx himself had put it, the most highly industrialised societies were the stage where the revolution would take place. The more advanced capitalist country would see intensified class struggle and the ultimate collapse of Capitalism, its example guiding the rest of the nations. The American exceptionalism (by which is meant, here, the fact that America did not fulfil Marxian predictions nor did it witness the rise of a significant socialist movement) baffled many prominent socialists, including Engels and leading Russian revolutionaries. Lenin and Trotsky were "deeply concerned with American exceptionalism, for it questioned the inner logic of Marxism," (p. 16) and as early as 1906 leading intellectuals were trying to understand the inconsistency, German sociologist Werner Sombart writing a cornerstone analysis on the subject. Influential Marxists, recognizing that "the assumptions of historical material-

* Universidade do Minho, CEHUM, Braga, Portugal. 
ism required that the United States should be in the lead politically" (p. 17) were left distraught at the failure of the socialist movement in America: "The United States was a living contradiction of... Marxian theory,' and raised fundamental questions about its validity" (p.18). In order to explain the paradox and justify this, socialists and left intellectuals advanced their own set of arguments, which Martin Lipset and Gary Marks browse through Chapter 1.

In the remaining chapters, via historical and comparative analysis with other countries, the authors go through what they consider to be some of the more convincing reasons for the failure of Socialism to play a major role in the country as well as reviewing and putting to the test some of the left's pretexts. One of these was related to the American political and party system, considered to hinder the development of a Socialist party. The electoral system was singled out by the socialists as favouring the party duopoly of Republicans and Democrats. The winner-takes-all system, in which the candidate with the most votes gets elected, is harmful to small parties because it induces voters to opt for the 'lesser evil'. Instead of voting for the party of their choice, voters prefer not to waste their ballot on a candidate with limited chances of winning. This tactical voting, of choosing the major party that best represents their interests, strengthens the two-party system and effectively closes the door on all others. However, as the authors are quick to point out, this does not explain why socialist candidates have fared worse in polls than other third parties and protest candidates. Even the "gift of the suffrage", the extension of voting rights to white males in the early years of the Republic, cannot be blamed as having inhibited classconsciousness among workers. Rather, the authors argue, it was the existence of strong and established parties based on ethnicity, religion and community that absorbed workers and immigrants. In a country of multiple national backgrounds and religious denominations, Republicans and Democrats appealed to voters based on their national and religious identities rather than class. This difficulty in approaching the diverse composition of workers was greatly enhanced when it came to win the support of immigrants. Class identity could not overcome the religious and ethnic distinctions that were imprinted in people newly arrived to a strange country and that could only rely on others from the same background for support. Moreover, the unions were dominated by "native" workers, mostly Anglo-Saxon or North-European and Protestant, whilst "new" workers, Irish and southern European and Catholic, were discriminated. 
Socialists, already having trouble courting the unions, never managed to get beyond this and alienated the mass of immigrants that could have proved fertile ground for their purposes.

The relationship between the unions and the socialists, or rather thelack thereof, was, according to the authors, a fundamental aspect that crippled the latter's hopes of assuming the role of leadership among workers. Socialists in America had a dogmatic view of their ideology which barred them from pragmatic approach and cooperation with others that could have enabled them to increase their political leverage. As such, "the American Socialist party was one of the most orthodox Marxist parties in the democratic world" (p. 160). It did not help that sectarianism was heightened after the Russian Revolution in 1917, with the eventual split of those supporting the revolution in Russia to form the Communist party. Incapable of uniting, socialists were also incapable of winning over the unions and pursued a policy of blocking "attempts to create a more encompassing labor party, fearing this would dilute socialist ideology and control" (p. 200). The sectarian drive to preserve ideological purity, ironically, is ascribed to the influence of Protestant sectarianism in America. The propensity among Protestants to fracture on questions of doctrine was paralleled by the socialists who "acted as if it were better to be right than effective" (p. 202). Thus, they came to face labour unions that were, themselves, the product of broad features of American society and culture, namely antistatism and individualism. Socialism was running "against deep libertarian currents in American culture" (p. 98). Unions opposed the extension of the role of the state; the two bigger federations of labour "rejected socialism on antistatist grounds" (p. 98).

The question of America's set of values is credited by the authors as having been one of the main reasons why Socialism failed: "American values - political structure - heterogeneous working class - party/union split: the interaction of these four factors holds the key to why socialists failed in America" (p. 264). Recent American historiography views 'American exceptionalism' with suspicion which might help to explain the authors' reluctance to delve deeper into a subject that Socialists' themselves pointed as being one fundamental reason behind their failure to achieve prominence in America. As the authors point out, many of the explanations given by Socialists "engage the question of how the United States differs from other advanced industrial societies (...) these are surprisingly positive evaluations and overlap consider- 
ably with the ideas of Alexis de Tocqueville, the father of 'American exceptionalism"' (p.11). Nonetheless, despite the importance attributed by them to explain the failure of Socialism, Lipset and Marks prefer not to explore the impact of America's cultural and political principles or, in a word, "Americanism" which the authors define as "an 'ism' or ideology in the same way that communism of fascism or liberalism are isms. The American ideology, stemming from the Revolution, can be subsumed in five words: antistatism, laissez-faire, individualism, populism and egalitarianism" (p. 30). Notwithstanding this opening, the theme is not developed and despite a few remarks throughout the book it isn't until the last chapter that the authors claim that "Distinctive elements of American culture - antistatism and individualism - negated the appeal of socialism for the mass of American workers" (p.266). A more profound analysis of that effect is lacking in their work.

The authors claim that one of the effects of Socialism's failure in America is a weakened lower-class political power, i.e., their ability to influence, via organized power, the legislative process. But that interpretation arises from the fact that Lipset and Marks are overly concentrated in the development of Socialist and Communist parties as representatives of the lower-classes and that only up until the 1930's. The investigation of socialist-influenced parties and candidates after that date is residual, if at all present. Even more influential is the study of socialist-influenced policy, which is all together absent in the book. Indeed, a host of legislative measures after the New Deal have been enacted that are statist economic and social policies and go a long way to meeting the demands of the lower-class. One only has to think of Harry Truman and the "Fair Deal" or Lyndon Johnson and his "Great Society" programme. Even if recently, as they claim, "socialist and labor parties have dropped statist economic policies that they inherited from their socialist past" (p. 262), it would be worth a look into the impact of statist social policies and their effect on American society at large and their potential to shift cultural an political values in America. As the authors remind us, "cultural values constrain the kinds of social institutions that are created in a society, and these institutions - schools, government bureaucracies, churches, etc. - help shape beliefs" (p. 265). Government and education policies can go a long way when coupled with social policies in shaping a society. 